American Journal of Applied Sciences 8 (3): 267-270, 2011

ISSN 1546-9239

(C) 2010 Science Publications

\title{
The Effect of Rapid Thermal Annealing Towards the Performance of Screen-Printed Si Solar Cell
}

\author{
Shahrul Anizan, Cheow Siu Leong, Khairymaza Lee Yusri, \\ Nowshad Amin, Saleem Zaidi and Kamaruzzaman Sopian \\ Solar Energy Research Institute, \\ University Kebangsaan Malaysia, Bangi, Selangor, 43600, Malaysia
}

\begin{abstract}
Problem statement: Solar cells are used to capture the photons which generate the energy. However the efficiency of the cells to turn the amount of photon to electricity needs to be high and so the cells enhancement is needed. This involved the whole process of the developing of the cells, thus annealing process is one of the important steps that needs to be optimised. Approach: Only Si solar cells will be discussed and the processes involved would be metal contact screen printing and metal paste co-firing. The contacts were first screen printed with Al paste for the rear side and Ag paste for the front side of the cell. Cells are then fired in the annealing furnace using selected temperature profile. Few sets of temperature profiles were used in every cycle. Results: After the IV characteristics were measured such as Voc, Isc, Pmax and fill factor, it shows that when higher annealing temperature of the profile was used, all the parameter will increase accordingly. However, profile with the highest annealing temperature will burn the paste as it will decrease the quality of the cell. This is considered as over heat to the paste. Conclusion: So by optimising the thermal treatment of the annealing process does improve the performance of the Si solar cell.
\end{abstract}

Key words: Thermal annealing, thermal treatment, solar cell, screen printing, paste co-firing, generate energy, global warming, energy technologies, silicon substrate, optimum firing cycle, metallization process, energy consumption

\section{INTRODUCTION}

As solar energy is one of the windows as the alternatives, the technology itself is widely developing. To generate energy from solar, a device call solar cell is needed. The technology of solar cell has been blooming since mid 70's. The researches were done by several organisations. Today there are many types of solar cell in the market. It came with various sizes, types of cells and also various efficiencies. The solar cells today considered as the third generation of cells due to its new criteria and technologies involve in developing it. The commonly used today are crystalline silicon and also thin film solar cell. Thin film is favourable due to its thinness and portability; however crystalline silicon is favourable due to its high efficiency to convert light in to electricity. This comes to a need in enhancing the crystalline silicon technology.

In other researches, it was shown surface texturing can be considered as a good candidate to solve the efficiency problem of solar cell (Abdullah et al., 2009).
However, the optimization of the cell contacts is also a good option with less experimental procedure. Front and back contact metallization can be realized by screen printing of a metal paste. In industrial production the most commonly applied technique for the front side metallization of silicon solar cells is screen printing, a reliable and well-understood process with high throughput rates (Erath et al., 2010). Silicon wafer that usually used is p-type [100]. After the doping process the wafer is covered by n-type substrate. The rear of the cells will be applied with a layer of aluminium and alloyed into the cell at temperatures above the Si-Al eutectic. The energy conversion efficiency of a solar cell can be significantly increased with the improvement of material properties and design or structures of the cells (Kabir et al., 2010). Figure 1 shows the schematic diagram of various designs of screen printed silicon solar cells. Compare to the earlier cells, today solar cells are chemically textured and also layered with an anti-reflection coating to increase the efficiency.

Corresponding Author: A.W. Shahrul, Solar Energy Research Institute, University Kebangsaan Malaysia, Bangi, Selangor, 43600, Malaysia Tel: +603-8921 4596 

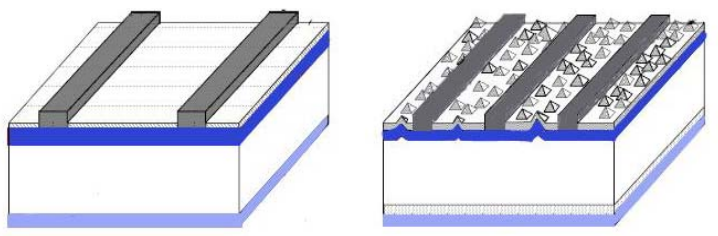

Fig. 1: (Left) Silicon solar cell developed in the earlier generation. (Right) Chemical textured solar cell with anti-reflecting coating

Temperature profile needs to be correctly determined so that the optimum firing cycle can be obtained. It is important to have an optimum firing cycle in order to get a better solar cell. Solder paste consist of solvents and resin, it might also made from organic compound. At certain temperature these solvents and resin will evaporate or burn off. It is a required as after the evaporation and burn off of the resin and solvents, the metal compound will commence to take effect. So, the temperature zones need to be set so that each zone will deliver the metallization process upon the paste.

Compared to photolithography and buried contact technologies, screen printing technology is relatively simple, time-saving and cost-effective and it reduces chemical wastes with little or no environment impact. To produce high efficiency solar cells with these methods, one needs to exert careful control over the parameters, such as the co-firing conditions and screen printing process (Kwon et al., 2010). The design of the top contact involves not only the minimization of the finger and bus bar resistance, but also the overall reduction of losses associated with the top contact. These include resistive losses in the emitter, resistive losses in the metal top contact and shading losses (Rohatgi et al., 2005). In the studies of Lee et al. (2008), the silver metal coverage is about $7 \%$ of cell top surface with metal thickness was thicker than $15 \mu \mathrm{m}$. The width of the metal line was smaller, so relatively this provides significant crosssectional area of the finger line.

\section{MATERIALS AND METHODS}

Two types of ovens were used for this experiment. Drying oven and annealing furnace. The drying oven was used to dry the solder paste for second printing and also before undergoing metalizing process.

The next oven is a rapid thermal annealing furnace, a model by Radiant Technology Corp with 6 temperature zones and also conveyer belt. The speed of the moving belt was fixed to 90 inches per minute, while the temperature zones were set according to the desired temperature profiles. The distribution of temperature zones are shown in Fig. 2, as the silicon

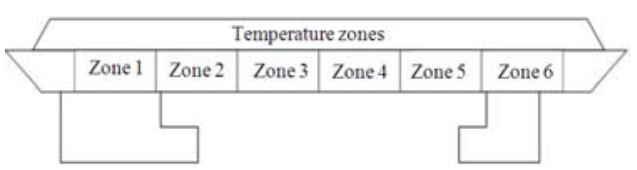

Fig. 2: Distribution of temperature zones in rapid thermal annealing furnace

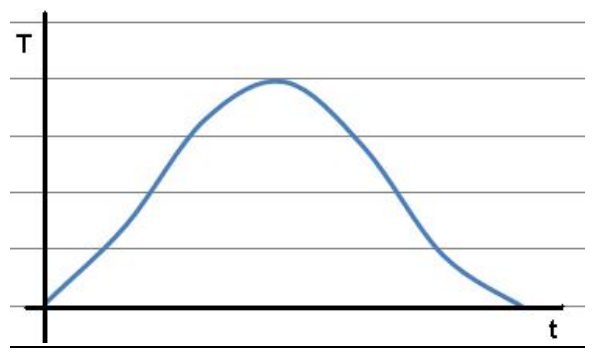

Fig. 3: General temperature profile graph (temperature Vs time)

wafers were feed in through the first zone and going out via sixth zone.

The general temperature profile graph (temperature Vs. time) is a bell shape graph as shown in Fig. 3. In this experiment, the general temperature profile was modified as in the graph 4 . All the temperatures were change with the same ratio for each of the silicon wafers.

Wafers are screen printed using screen printer. Two types of paste were used for both rear surface and front surface of the wafers. Each type of solder paste has its own temperature reaction range. The solder paste that used in this study is Ferro FX53-038, aluminium type for rear surface while for the front surface, Ferro CN33-462, silver type was used. The firing process, rapid thermal annealing need to meet the general pastes reactive temperatures and the temperature process are shown in the Table 1.

Referring back to the proposed temperature profile, the first zone is when the first temperature process took place. The second and the third zone are the zone where the second temperature process begins to react and the fourth and the fifth are the third temperature process took effect. The last zone is cooling zone for the wafer not to experience a sudden temperature change as such, the wafer will cracked or breaked. By repeating the process, the optimum firing cycle should be determined.

Experiment procedure: In this experiment 5 pieces of solar cells were used. All the cells are in the same batch that has gone through cleaning, texturing, doping process and edge isolated. This is important because we are going to evaluate the effect of various temperature profiles during the annealing process towards the cell efficiency produced. 


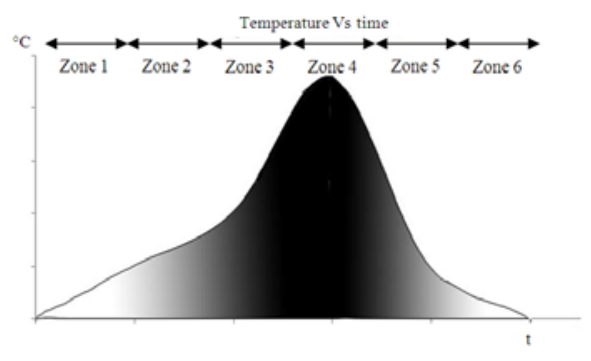

Fig. 4: General temperature profile used in rapid thermal annealing

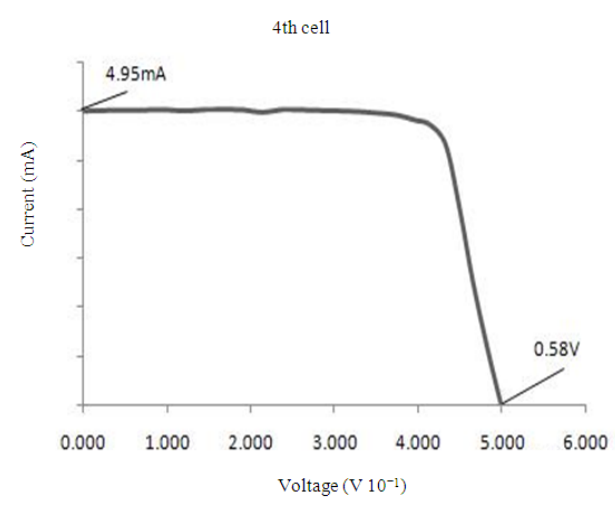

Fig. 5: IV Characteristic for the forth cell

Table 1: Process involve in each temperature range of solder pastes.

\begin{tabular}{ll}
\hline Temperature $\left({ }^{\circ} \mathrm{C}\right)$ & Process \\
\hline $200-300$ & Solvents and resin will evaporate or burn off \\
$450-500$ & Silver/aluminium particles will start sintering \\
$600-700$ & Frit system in black enamel become fluid \\
\hline
\end{tabular}

In screen printing current research has been done by using 6" p-type Si wafer [100]. After the doping process the cells has been through the passivation process. In this process a layer of $\mathrm{SiN}$ has been created about $105-200 \mathrm{~nm}$.

For metallization process, Ferro AG (33-462) has been used for the front contact while Ferro $\mathrm{Al}$ (53-038) has been used for the back contact. The cells are then fired

While during the rapid thermal annealing process, the cell is then fired with the temperature profile from $200-900^{\circ} \mathrm{C}$ with 6 zones. A base temperature profile was set for the first cell. And then the temperature profile was increased equally for another four cells. The solar cells were then tested for its fill factors, open circuit voltage and short circuit current using the LIV tester.

\section{RESULTS}

After the fourth cell has been tested, it was found out that the fill factor is 56.71 with $0.58 \mathrm{~V}$ of $\mathrm{V}_{\mathrm{oc}}$ and

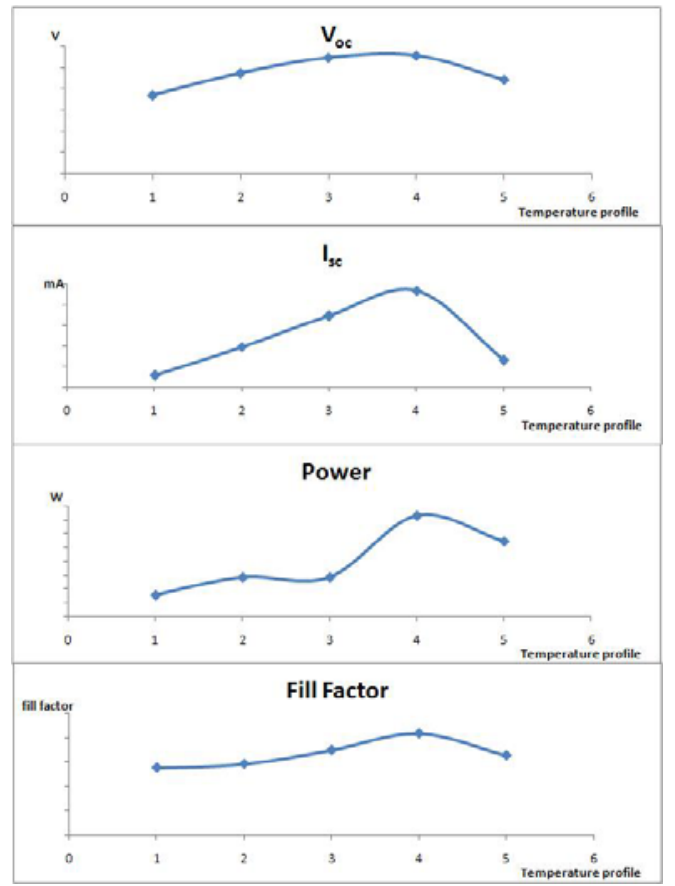

Fig. 6: Comparison of the various factors upon the 5 temperature profile of the rapid thermal annealing

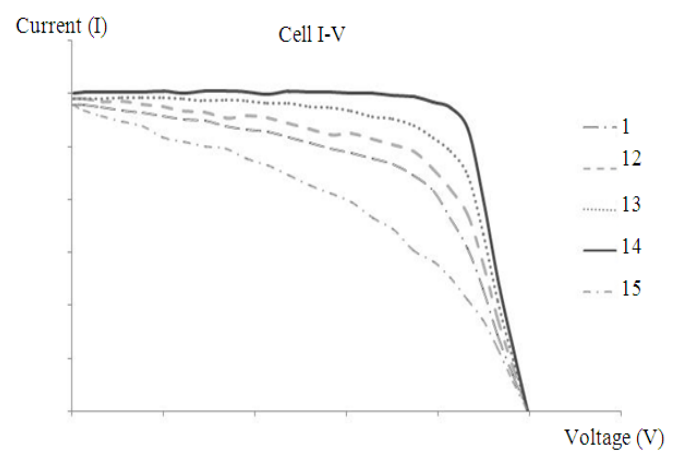

Fig. 7: Comparison of $5 \mathrm{I}-\mathrm{V}$ curves from 5 different temperature profiles

$4.95 \mathrm{~mA}$ of $\mathrm{I}_{\mathrm{sc}}$. The IV curve is shown in Fig. 5. The completed cells were then tested it performance using the Light $\mathrm{I}-\mathrm{V}$ tester. The variables that taken to consideration are the $I_{\mathrm{sc}}, V_{\mathrm{oc}}$, fill factor and cell power. All the information can be summarised in the Fig. 6. While Fig. 7 shows the comparison of the IV curves.

\section{DISCUSSION}

Rapid thermal annealing: Annealing is the process to complete the metallisation of a solar cell. Depending on 
what type of furnace used, the method are varies. Hightemperature annealing is traditionally done in roller or belt furnaces or in tube furnaces. Rapid thermal annealing (RTA) has been established since several years as an efficient annealing technology providing well controlled thermal budgets and a fast processing (Rau et al., 2009). In this experiment, 6 zones annealing furnace with conveyer belt was used. The temperature profiles used are relative to the Fig. 6. Depend on how many zone that the annealing furnace have, the temperature profile is then optimised.

The first 3 zones are the warming up zone. This is due to the silicon wafer cannot experience a sudden temperature change. The fourth zone the when the annealing take place while the last 2 zone is cooling zone (before the wafers going out from the furnace). After the first cell annealed, the second was continued to anneal with each temperature zone were increased equally with respecting to the first cell temperature (basic profile). Same process was repeated until the fifth cell.

Performance testing: It shows that as the annealing temperature increased, all the performance values are also increased. It means that certain temperature is required to complete the metallisation or to completely vaporise the organic substance in the paste. But when the temperatures are too high, it will burn most of the paste on each surface which is then reduce the cell performance. Too high temperature will burn the paste as the organics substance doesn't have sufficient time to evaporate as it burn with the paste. However it is known that overall, the crystal defect may affect the performance of the solar cell even the fabrication of the cell is good (Haunschild et al., 2010).

\section{CONCLUSION}

Lots of factors need to consider in optimizing the silicon solar cell contacts. The temperature profile during the annealing process does influence the results of the produced cells. Other factors that can influence the result are the design of the front contact and also type of paste use to make the surface contact. Even though some results are known information, this can be the guide or addition for the future reference. Further research is still going on in order to improve and optimize the cell.

\section{ACKNOWLEDGMENT}

This study has been supported by the Ministry of Science Technology and Innovation Malaysia, Solar
Energy Research Institute (SERI) University Kebangsaan Malaysia and Gratings Inc USA. Authors gratefully thank Prof K. Sopian and Dr Saleem for sharing the knowledge.

\section{REFERENCES}

Abdullah, H., A. Lennie, M.J. Saifuddin and I. Ahmad, 2009. The effect of electrical properties by texturing surface on GaAs solar cell efficiency. Am. J. Eng. Applied Sci., 2: 189-193. DOI: 10.3844/ajeassp.2009.189.193

Erath, D., A. Filipović, M. Retzlaff, A.K. Goetz and F. Clement et al., 2010. Advanced screen printing technique for high definition front side metallization of crystalline silicon solar cells. Solar Energy Mat. Solar Cells, 94: 57-61. DOI: 10.1016/j.solmat.2009.05.018

Haunschild, J., M. Glatthaar, M. Demant, J. Nievendick and M. Motzko et al., 2010. Quality control of ascut multicrystalline silicon wafers using photoluminescence imaging for solar cell production. Solar Energy Mat. Solar Cells, 94: 2007-2012. DOI: 10.1016/j.solmat.2010.06.003

Kabir, M.I., Z. Ibrahim, K. Sopian and N. Amin, 2010. Effect of structural variations in amorphous silicon based single and multi-junction solar cells from numerical analysis. Solar Energy Mat. Solar Cells, 94: $\quad 1542-1545 . \quad$ DOI: 10.1016/j.solmat.2009.12.031

Kwon, T., S. Kim, D. Kyung, W. Jung and S. Kim et al., 2010. The effect of firing temperature profiles for the high efficiency of crystalline Si solar cells. Solar Energy Mat. Solar Cells, 94: 823-829. DOI: 10.1016/j.solmat.2009.12.032

Lee, J., N. Lakshminarayan, S.K. Dhungel, K. Kim and J. Yi, 2008. Optimization of fabrication process of highefficiency and low-cost crystalline silicon solar cell for industrial applications. Solar Energy Mat. Solar Cells, 93: 256-261. DOI: 10.1016/j.solmat.2008.10.013

Rau, B., T. Weber, B. Gorka, P. Dogan and F. Fenske et al., 2009. Development of a rapid thermal annealing process for polycrystalline silicon thin-film solar cells on glass. Mat. Sci. Eng. B, 159-160: 329-332. DOI: $10.1016 /$ j.mseb.2008.05.007

Rohatgi, A., E. Abasifreke, H.M. Mohamed, V. Meemongkolkiat and B. Rounsaville et al., 2005. High efficiency screen-printed solar cells on textured mono-crystalline silicon. Proceedings of the 15th International Photovoltaic Science and Engineering Conference, Oct. 10-15, Georgia Institute of Technology, Shanghai, China. http://smartech.gatech.edu/handle/1853/25928 